\title{
Conception of cable-stayed curved deck: the effects of unilateral suspension
}

\section{Concepção de tabuleiros curvos e estaiados: os efeitos da suspensão unilateral}

G. M. CHUNG a gabi.chung@gmail.com

F. R. STUCCHI a frstucchi@gmail.com

\begin{abstract}
In systems of suspended cable bridges, the cable-stayed bridges have been widely used because of its capacity to overcome large spans and not require large areas of support during their execution, minimizing interference with existing vehicle flow or overcoming large spans in rivers and channels that require space to the passage of vessels. In addition to this structural advantages, they are aesthetically well accepted by society, valuing the urban space and often making it a landmark.

This paper aims to describe the influence of unilateral suspension of decks on the behavior of cable-stayed bridges with curved decks through structural models in order to evaluate whether structural gains or losses are relevant to project considerations. Results indicated that stresses variation in the deck depends not only on the position of the cables and their forces (which depends on the stiffness of the deck), but also on the cable itself and the central pylon.
\end{abstract}

Keywords: cable-stayed bridge, footbridge, curved deck, concrete.

\section{Resumo}

Dos sistemas de pontes suspensas por cabos, as estaiadas têm sido largamente utilizadas devido à sua capacidade de vencer grandes vãos e não demandarem grandes áreas de apoio durante sua execução, minimizando as interferências com o fluxo de veículos já existente ou vencendo grandes vãos em rios e canais que necessitam de espaço para passagem de embarcações. Além dessas vantagens estruturais, são esteticamente bem aceitas pela sociedade, valorizando o espaço urbano e muitas vezes tornando-o ponto de referência.

Este trabalho visa descrever a influência da suspensão unilateral do tabuleiro no comportamento de pontes estaiadas curvas através de modelos estruturais aplicados a passarelas, a fim de avaliar se os ganhos ou perdas estruturais são relevantes para as considerações de projeto. Os resultados indicaram que a variação dos esforços no tabuleiro depende, além do posicionamento dos cabos e suas forças (que por sua vez dependem das rigidezes do tabuleiro), dos próprios cabos e do mastro central.

Palavras-chave: ponte estaiada, passarela, tabuleiro curvo, concreto. 


\section{Introduction}

The study of conception of cable-stayed bridges with curved decks is still not widespread in Brazil. With the improvement of techniques and Brazilians professionals, studies on these types of structural solutions have been increasingly deepened, leading to the study and design of new solutions in order to optimize the available space and resources and minimize impacts on roadway structure.

The first cable-stayed bridge in Brazil began to be built in the year 2000. It is located in São Paulo and known as Santo Amaro BridgeStation. It is noted that the use of cable-stayed bridges is still very recent in Brazil due to the fact that technology is not dominated at all levels involved, but mainly because the governors just started to understand that in some special cases it is preferable a higher investment in order to have a more attractive structure.

A highlighted cable-stayed bridge in Brazil is the Octávio Frias de Oliveira Bridge, which was inaugurated in 2008 in the city of São Paulo. The bridge, which is part of the Real Parque Road Complex, is composed of two independent curved decks that cross Pinheiros River and is the only cable-stayed bridge in the world with two curved decks connected to the same pylon (Berger [1]).

In situations where a straight way would not be sufficient to overcome an obstacle, curved bridges become necessary, and the knowledge of the techniques and theories underlying curved cable-stayed bridges is a requirement for the study of a more favorable and/or optimized design, where all the factors influencing its behavior must be evaluated, such as: curvature, pylon position, cables position and inclination and cross section geometry.

Therefore, structural models were applied to footbridges that allow evaluating the influence of unilateral suspension of the deck. When comparing models results with deck's suspension by the inner side and the outer side of the curve, it is possible to evaluate the most favorable performance of the structure for each situation. The parametric study of these effects and their understanding is one of the most important purposes of this paper.

\section{Methodology and formulation}

\subsection{Formulation and theories}

Structures in general are well described by the Linear Theory of Elasticity, or simply Theory of Elasticity, in which two hypotheses are adopted and lead to the linearity of the formulated problems: Geometric Linearity and Linear Elasticity. In the first, no distinction is made between the deflected and undeflected shapes when formulating equilibrium equations. In the second, also known as Physical Linearity, it is assumed that stress and deformation components obey a linear relationship through the elastic stiffness modulus.

The formulations of linear theory lead to satisfactory results in structures with small displacements. In the case of cable-stayed bridges, in which the elements are lighter and slenderer, such hypotheses are no longer valid, which leads us to extend the analysis to the Nonlinear Theory of Elasticity, where second-order effects are considered fundamental to stability analysis of more flexible elements, as is the case of the stay cables that deform according to a catenary quite sensitive to the tensile force, and also of the central pylon, which is compressed by great axial force transmitted through the stay cables. The software chosen for analysis writes the equations of equilibrium in the deformed position taking into account the effects of 2 nd order in both cables and pylon, so that Newton-Raphson's method for the solution of non-linear equations is used. Mathematically, the method is based on a gradual increase (incremental) of the load. These effects also exist in the deck which is quite compressed, but more rigid.

In curved beams, the calculation is more complex than in straight beams due to the interaction between flexion and torsion, which appear interconnected in the equilibrium equations. Moreover, when increasing the curvature, the torsion requests become considerable, which, on the other hand, determines an increase in distortion, i.e. deformation in the cross section, which generates transverse and longitudinal stresses that cannot be neglected.

For an infinitesimal curved beam element, according to Figure 1, the equilibrium equations are:

Equilibrium in y direction

$\frac{\mathrm{dV}}{\mathrm{ds}}=-\mathrm{p}$

Equilibrium in z direction

$\frac{\mathrm{dM}}{\mathrm{ds}}=\mathrm{V}-\frac{\mathrm{T}}{\mathrm{R}}$

Equilibrium in $\mathbf{x}$ direction

$\frac{\mathrm{dT}}{\mathrm{ds}}=\mathrm{t}+\frac{\mathrm{M}}{\mathrm{R}}$

\subsection{Methodology}

The main characteristic of cable-stayed bridges is the lightness of its structure, which results from the fact of having a series of intermediate supports represented by stay cables, which, despite their greater deformability, are efficient.

For curved cable-stayed bridges, the cables, besides being positioned to replace supports, should be so also to neutralize the effects of curvature, which is possible by varying their position and inclinations in the longitudinal and transverse planes.

In this paper, studies were performed for two configurations - inner and outer suspension - with tri-dimensional models of bars and cables in SCIA Engineer ${ }^{1}$ software, in which Finite Element Method

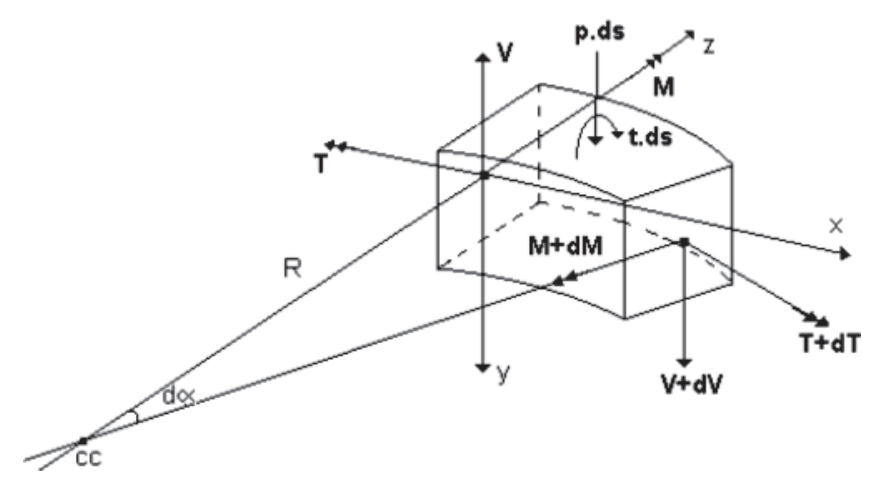

Figure 1

Curved beam element [2] 


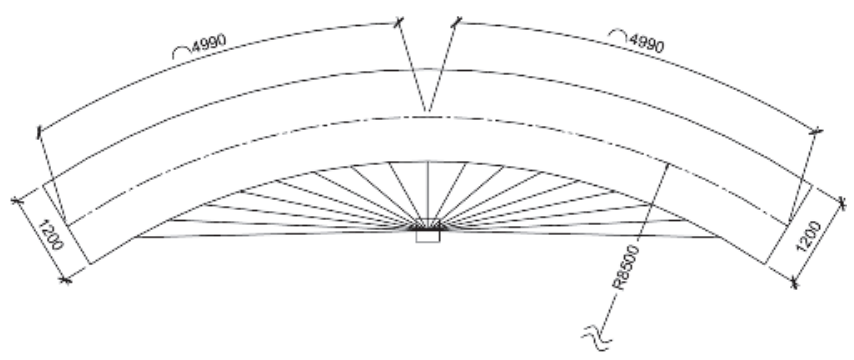

Figure 2

Plan view of the deck: suspension by inner side (units: $\mathrm{cm}$ )

1200

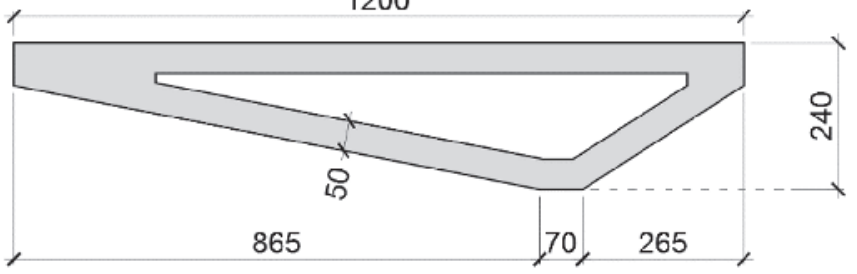

Figure 3

Deck cross section (units: $\mathrm{cm}$ )

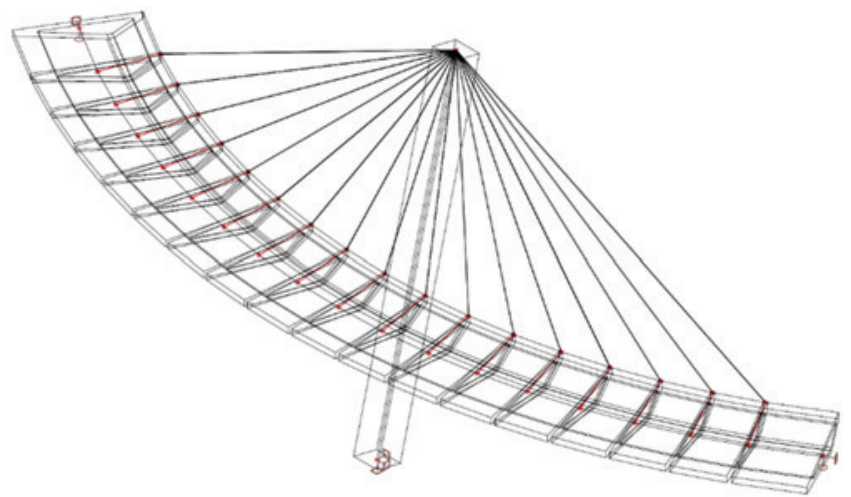

Figure 4

Model isometric view: suspension by inner side

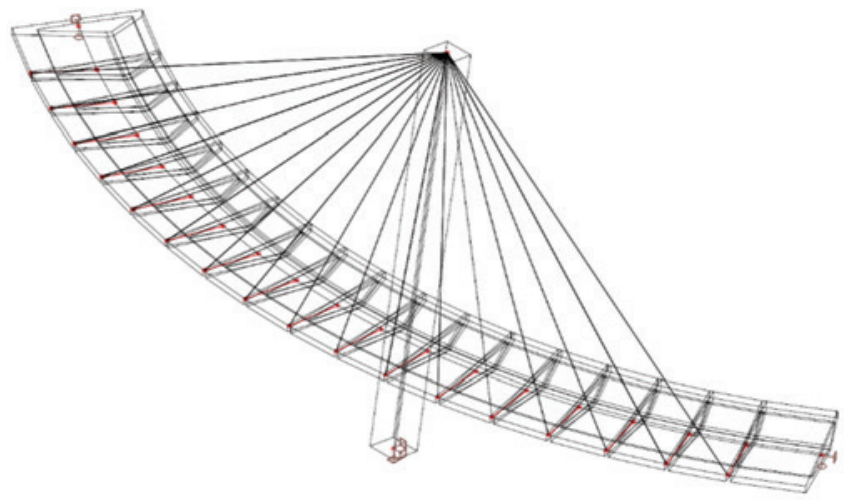

Figure 5

Model isometric view: suspension by outer side is used for non-linear analysis. The bars were used to represent deck and pylon, both of concrete, while the cables with fan arrangement represent the steel stay cables, whose flexural stiffness are admitted null. This software presents a tool for cable elements so that it is possible to specify an axial force to be considered early in the processing as an initial tensioning on the element. In addition, due to the catenary that the cable presents under the effect of its own weight, the cables would have to have their modulus of elasticity corrected as proposed by the German engineer Franz Dischinger so that the cable could be modeled as a bar. However, this adjust was not necessary because the software already considers the initial geometry of the cable element as its catenary at the beginning of the processing.

Therefore, in order to neutralize the structure initial deformation due to its own weight and to obtain a good distribution of moments in the deck, an initial tensioning in the cables was applied, whose determination is described in detail in Chung and Stucchi [3].

The physical properties of concrete and steel have complied with the recommendations of NBR 6118: 2014 [4].

As the unilateral suspension of the deck influences its behavior and each cable anchors in a transverse girder, rigid bars were used to simulate the connection of the deck to the cables, since such connection does not occur in the center of gravity of the cross section.

In addition, it is known that torsional forces may occur due to fact that shear center does not coincide with center of gravity of the cross section. However, considering that in box sections these points are close, it is usual to consider the axis of the bar that represents the deck in the center of gravity, as it was done in this paper.

To evaluate the performance of the structure against curvature, each configuration was compared to a secondary model, where the deck is made straight in order to neutralize the effects of $M / R$ portion of the equation (3).

Finally, the results were compared to a bilateral suspension model.

\subsection{Strutural model}

The study was developed for a footbridge with concrete compressive strength equal to $45 \mathrm{MPa}, 50 \mathrm{~cm}$ thick box girder, 100 $\mathrm{m}$ length and $85 \mathrm{~m}$ radius, symmetrically suspended by stays spaced every $5 \mathrm{~m}$, using 17 stay cables. Figure 2 and 3 illustrate the geometry.

The pylon was designed inclined, forming an angle of approximately $80^{\circ}$ with the horizontal. It has a total height of approximately $40 \mathrm{~m}$ with all degrees of freedom restrained on the base, so that the deck is positioned on the pylon's half height, and square cross-section of $5 \mathrm{~m} \times 5 \mathrm{~m}$.

The ends of deck are restrained to vertical and tangential displacements, conditioning the abutment with anchor block, and restrained to the torsional rotation, so that it simulates the connection with the pier cross beam.

Figure 4 to 6 present the isometric views of the structural models with internal, external suspension and bilateral suspension, respectively. 


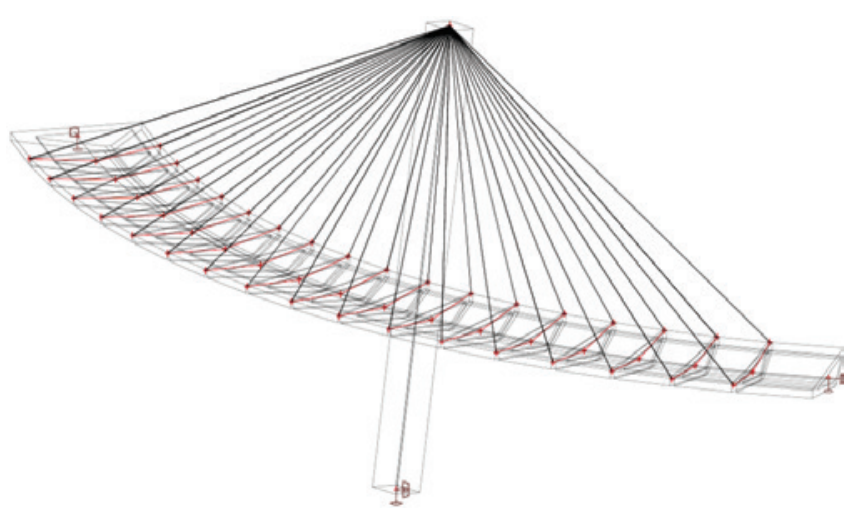

Figure 6

Model isometric view: bilateral suspension

According to the requirements of standard NBR 7188: 2013 [5], the live load on pedestrian footbridges is a uniformly distributed load of intensity $p=5 \mathrm{kN} / \mathrm{m}^{2}$, not increased by the impact coefficient. The load is applied on section centroid, distant from 0.134 $\mathrm{m}$ of the middle axis of the deck, which causes a corresponding torsion of $8,04 \mathrm{kNm} / \mathrm{m}$ to be considered.

The internal torsion stresses in deck also result from the fact that the cross section centroid does not coincide with the shear center, generating torsion for both permanent and accidental loads. Table 1 summarizes the cables installed forces, in which $L$ is the cable length and $\mathrm{N}$ the installed force.

\section{Results and discussions}

\subsection{Shear and moments diagrams: suspension by the inner side}

Figure 7 to 14 present shear and moments diagrams of the curved deck suspended by the inner side, in which "P" indicates permanent load and "L" live load.

A sharp curve in moment diagram is shown in Figure 13. This is due to the transverse load on the pylon due to its own weight which, by being tilted, causes bending. By decomposing the distributed load of the pylon's own weight $(\mathrm{W}=625 \mathrm{kN} / \mathrm{m})$, inclined by $10^{\circ}$ from the vertical, a transverse plot $(\mathrm{T})$ of approximately

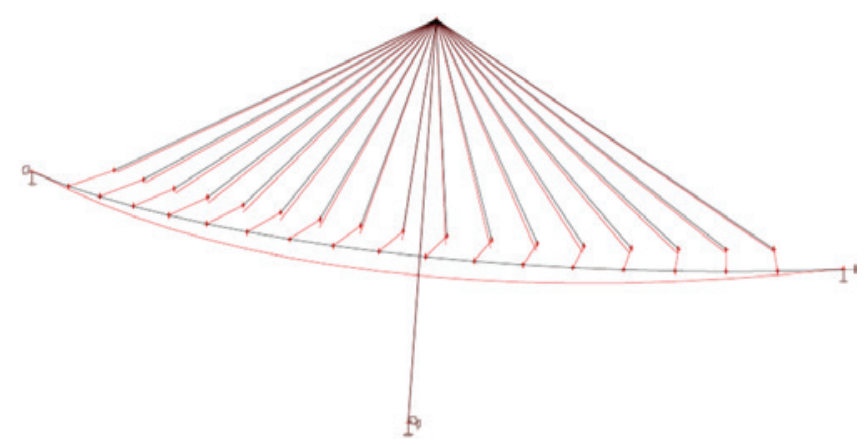

Figure 7

Deformed configuration: internal case

Table 1

Cables installed forces

\begin{tabular}{|c|c|c|c|c|c|c|}
\hline \multirow{2}{*}{ Cable } & \multicolumn{2}{|c|}{ Inner side suspension } & \multicolumn{2}{c|}{ Outer side suspension } & \multicolumn{2}{c|}{ Bilateral suspension } \\
\cline { 2 - 7 } & $\mathbf{L}(\mathbf{m})$ & $\mathbf{N}(\mathbf{k N})$ & $\mathbf{L}(\mathbf{m})$ & $\mathbf{N}(\mathbf{k N})$ & $\mathbf{N}$ int $(\mathbf{k N})$ & $\mathbf{N}$ ext $(\mathbf{k N})$ \\
\hline 1 & 43,21 & 3278,47 & 49,20 & 2654,09 & 1924,57 & 2941,34 \\
\hline 2 & 39,31 & 2656,05 & 45,23 & 3314,33 & 1047,82 & 2179,69 \\
\hline 3 & 35,52 & 2940,19 & 41,46 & 2950,95 & 1020,03 & 2082,07 \\
\hline 4 & 31,94 & 2792,90 & 37,96 & 2708,26 & 916,99 & 1905,44 \\
\hline 5 & 28,65 & 2555,21 & 34,80 & 2486,64 & 822,79 & 1746,26 \\
\hline 6 & 25,79 & 2314,96 & 32,12 & 2296,39 & 740,32 & 1609,97 \\
\hline 7 & 23,53 & 2114,36 & 30,05 & 2148,46 & 674,67 & 1504,12 \\
\hline 8 & 22,06 & 1981,00 & 28,74 & 2053,85 & 631,59 & 1436,46 \\
\hline 9 & 21,54 & 1934,13 & 28,28 & 2021,19 & 616,47 & 1413,10 \\
\hline 10 & 22,06 & 1981,00 & 28,74 & 2053,85 & 631,59 & 1436,46 \\
\hline 11 & 23,53 & 2114,36 & 30,05 & 2148,46 & 674,67 & 1504,12 \\
\hline 12 & 25,79 & 2314,96 & 32,12 & 2296,39 & 740,32 & 1609,97 \\
\hline 13 & 28,65 & 2555,21 & 34,80 & 2486,64 & 822,79 & 1746,26 \\
\hline 14 & 31,94 & 2792,90 & 37,96 & 2708,26 & 916,99 & 1905,44 \\
\hline 15 & 35,52 & 2940,19 & 41,46 & 2950,95 & 1020,03 & 2082,07 \\
\hline 16 & 39,31 & 2656,05 & 45,23 & 3314,33 & 1047,82 & 2179,69 \\
\hline 17 & 43,21 & 3278,47 & 49,20 & 2654,09 & 1924,57 & 2941,34 \\
\hline
\end{tabular}




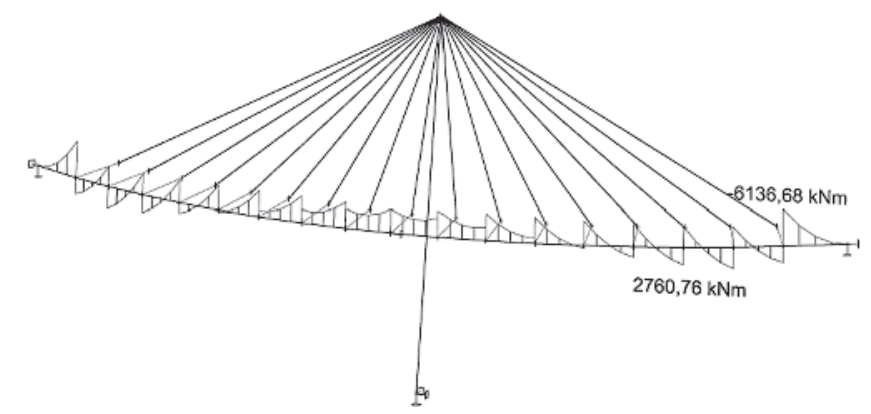

Figure 8

Bending moment on curved deck $(P)$ : internal case

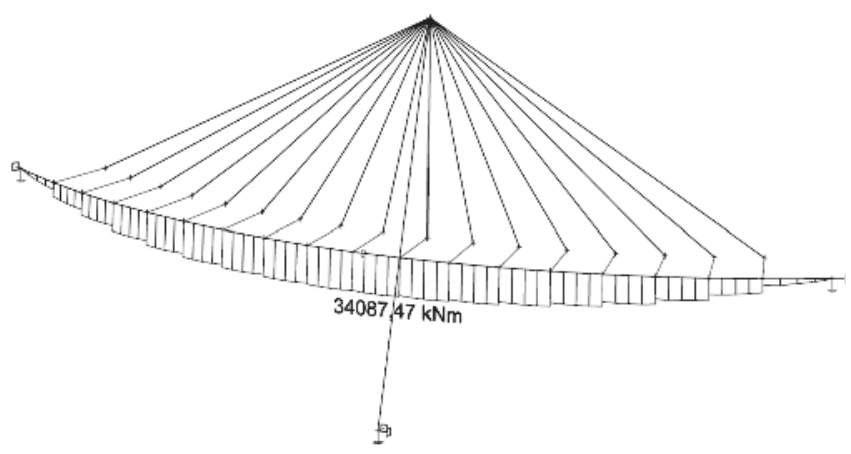

\section{Figure 9}

Bending moment on curved deck $(\mathrm{P}+\mathrm{L})$ : internal case

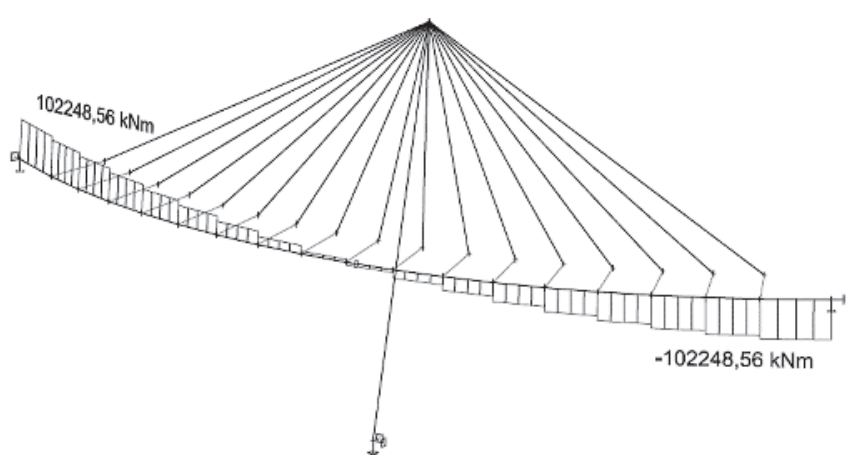

\section{Figure 10}

Torsional moment on curved deck (P): internal case

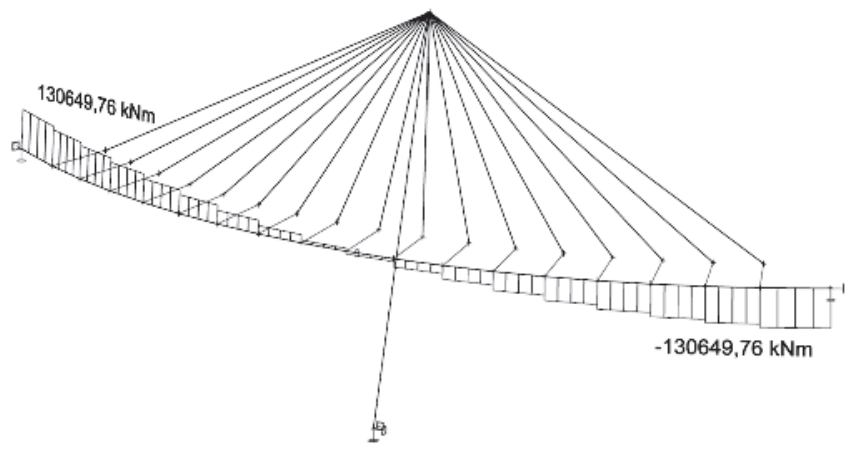

\section{Figure 11}

Torsional moment on curved deck $(\mathrm{P}+\mathrm{L})$ : internal case
$105 \mathrm{kNm} / \mathrm{m}\left(\mathrm{T}=\mathrm{W} \times \sin 10^{\circ}=625 \times 0,167 \approx 105 \mathrm{kN} / \mathrm{m}\right)$. Assuming, for simplification, that the structural scheme of the pylon is close to a fixed-pinned supported beam, the expected positive moment would be $9 \mathrm{~T} . \mathrm{L}^{2} / 128$, that is, $12220 \mathrm{kNm}$, a value close to the $13315 \mathrm{kNm}$ obtained.

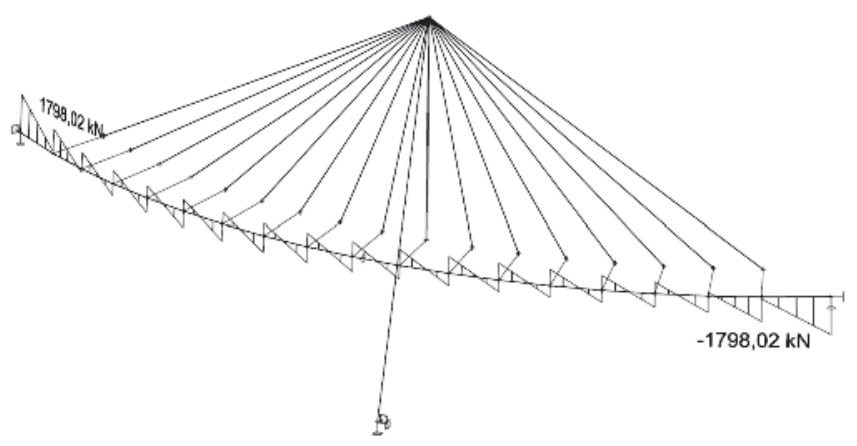

Figure 12

Shear force on curved deck $(\mathrm{P}+\mathrm{L})$ : internal case

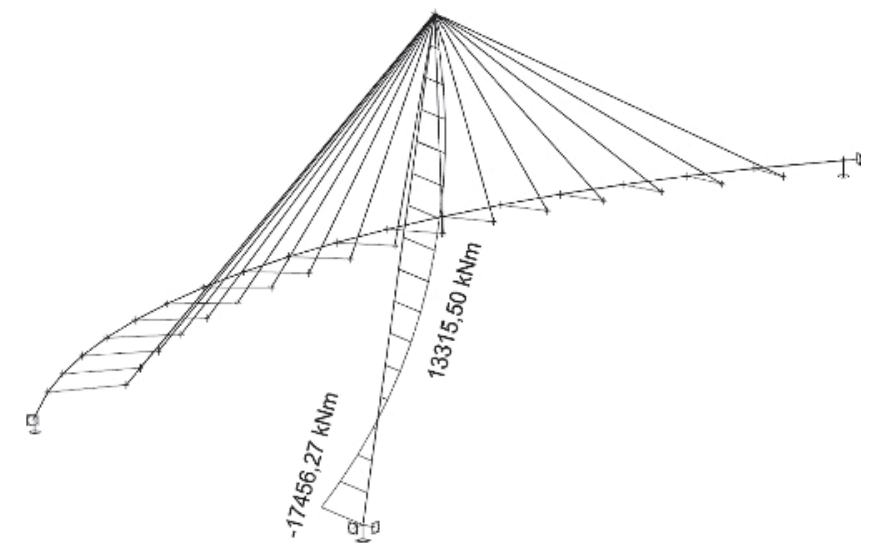

Figure 13

Bending moment on pylon (P): internal case

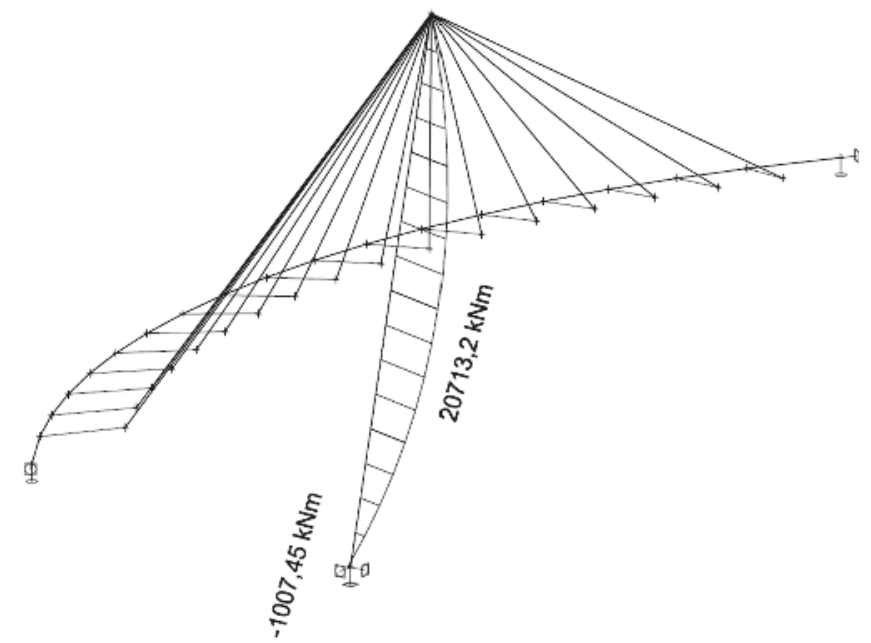

Figure 14

Bending moment on pylon $(\mathrm{P}+\mathrm{L})$ : internal case 
Table 2 summarizes the obtained results.

By developing the stress diagrams for the straight beam model (Figure 15), we have the results shown on Figure 16 and 17.

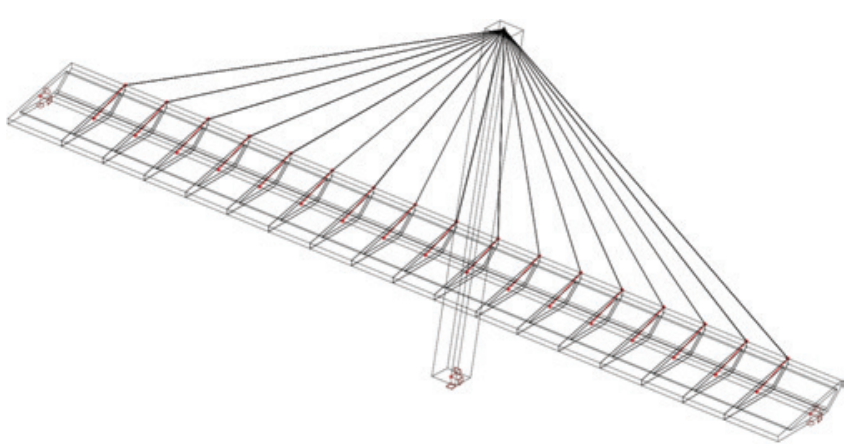

\section{Figure 15}

Model with straight deck: internal case

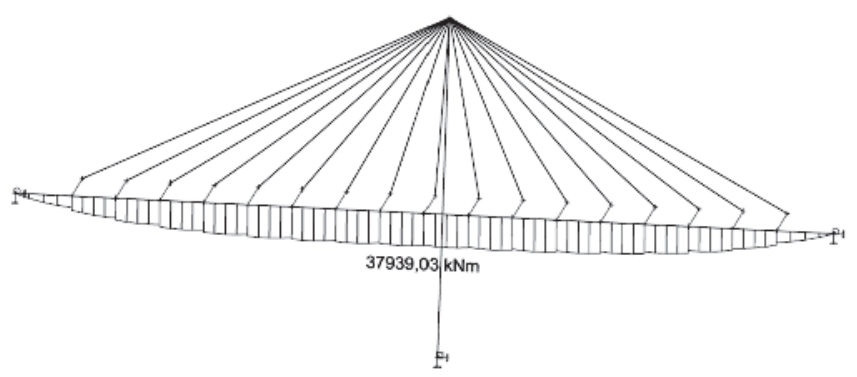

\section{Figure 16}

Bending moment on straight deck $(\mathrm{P}+\mathrm{L})$ : internal case

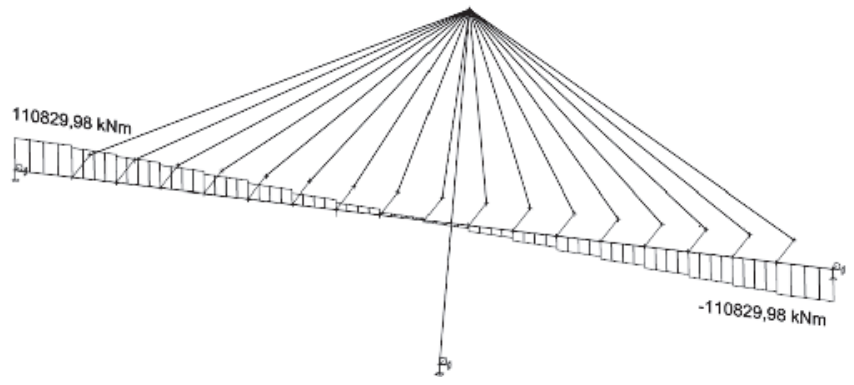

\section{Figure 17}

Torsional moment on straight deck $(\mathrm{P}+\mathrm{L})$ : internal case

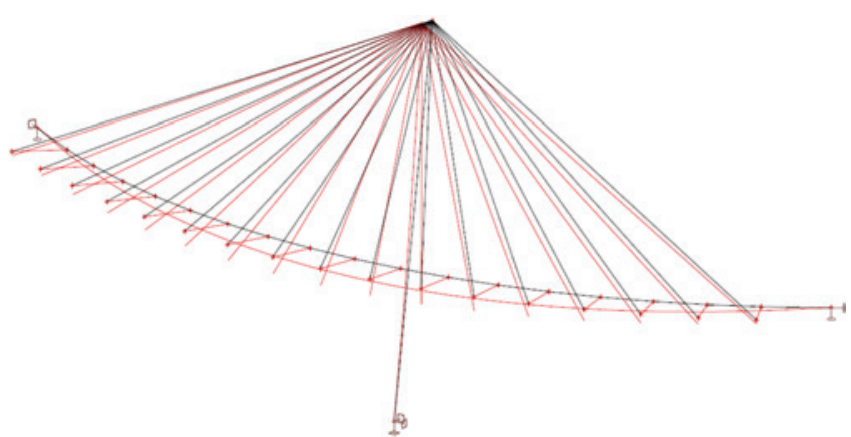

Figure 18

Deformed configuration: external case

\subsection{Shear and moments diagrams: suspension by the outer side}

Figure 18 to 25 present shear and moments diagrams of the curved deck suspended by the outer side.

\section{Table 2}

Moments and shear force summary in curved deck: suspension by inner side

\begin{tabular}{|c|c|}
\hline Forces & Results \\
\hline $\mathrm{M}_{\text {DECK }}(\mathrm{kN} \mathrm{m})$ & 34087,4 \\
\hline $\mathrm{T}_{\text {DECK }}(\mathrm{kN} \mathrm{m})$ & 130649,8 \\
\hline $\mathrm{V}_{\text {DECK }}(\mathrm{kN})$ & 1798 \\
\hline $\mathrm{M}_{\text {PYLON }}(\mathrm{kN} \mathrm{m})$ & 20713,2 \\
\hline
\end{tabular}

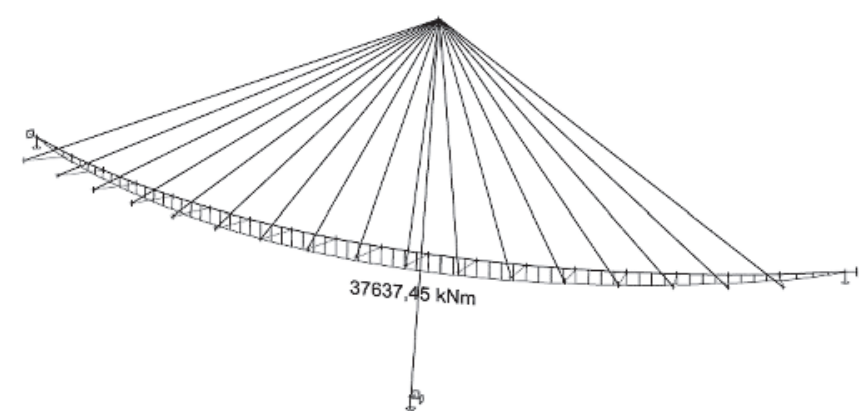

Figure 19

Bending moment on curved deck $(P)$ : external case

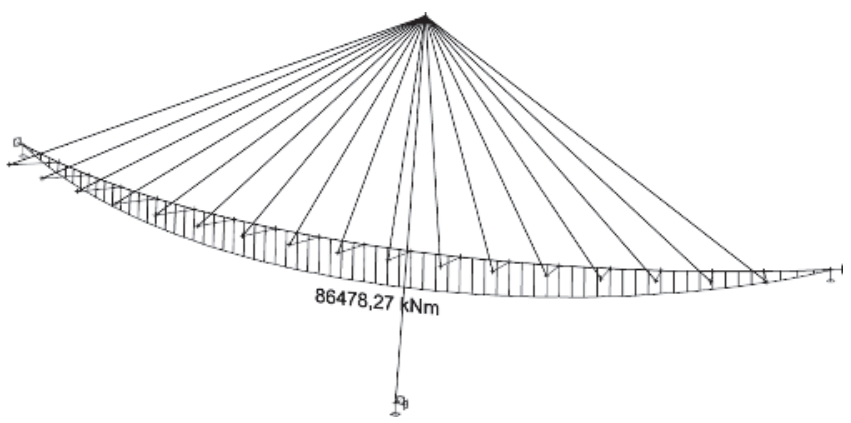

\section{Figure 20}

Bending moment on curved deck $(\mathrm{P}+\mathrm{L})$ : external case

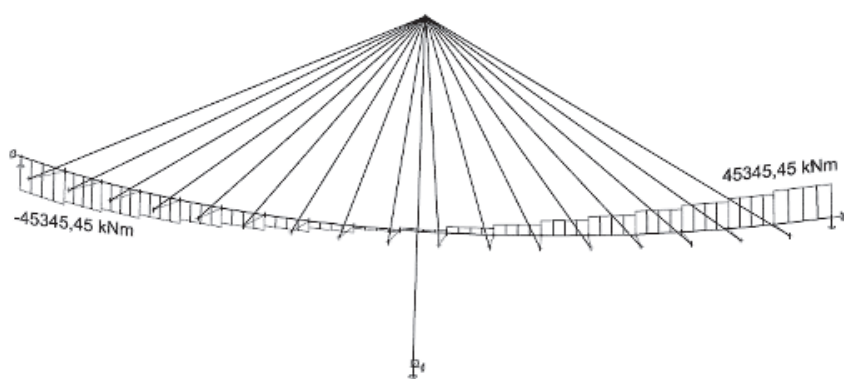

Figure 21

Torsional moment on curved deck (P): external case 
Table 3 summarizes the obtained results.

By developing the stress diagrams for the straight beam model (Figure 26), we have the results shown on Figure 27 and 28.

\subsection{Shear and moments diagrams: bilateral suspension}

Figure 29 to 36 present shear and moments diagrams of the curved deck suspended bilaterally.

Table 4 summarizes the obtained results.

\subsection{Comparisons}

A comparative summary of the unilateral systems is presented on Table 5.

When comparing the models with curved deck, it is verified that when the cables are external the torsion moment is noticeably reduced by the M/R portion given by equation ( 3 ) for approximately $20 \%$. However, bending moments increase 2,5 times.

On the other hand, in the system with internal cables, comparing the curved deck with the straight deck, the torsion is increased by the unfavorable $M / R$ portion and bending moments practically remain the same.

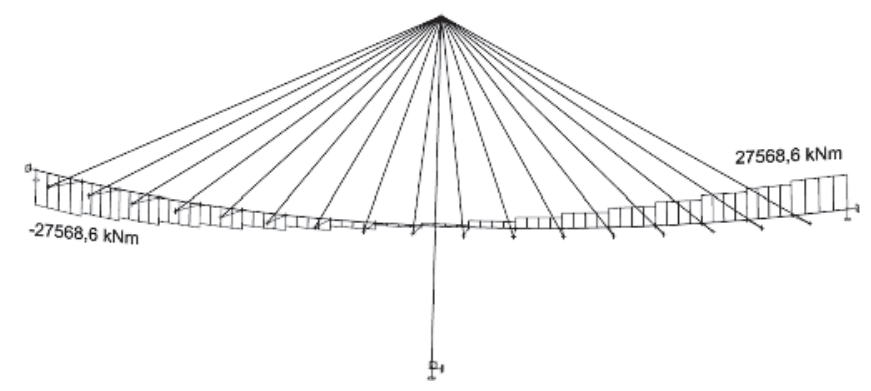

Figure 22

Torsional moment on curved deck $(\mathrm{P}+\mathrm{L})$ : external case

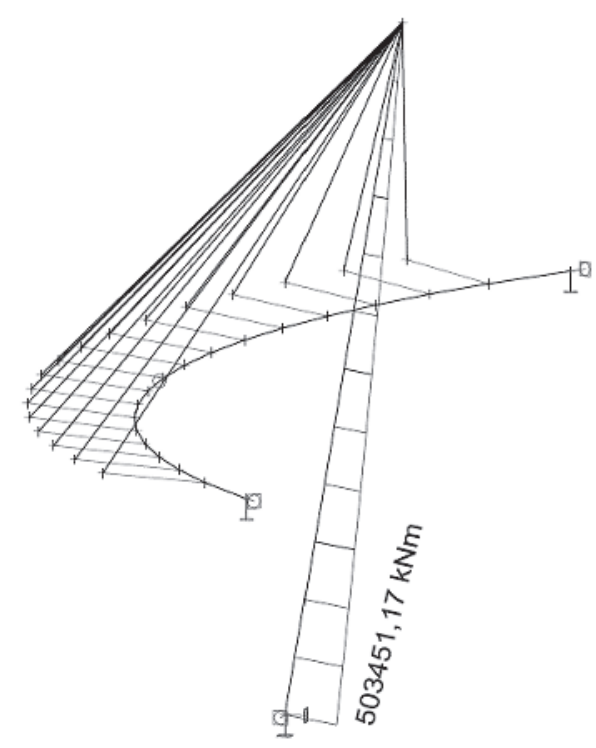

Figure 24

Bending moment on pylon (P): external case
Table 3

Moments and shear force summary in curved deck: suspension by outer side

\begin{tabular}{|c|c|}
\hline Forces & Results \\
\hline $\mathrm{M}_{\text {DECK }}(\mathrm{kN} \mathrm{m})$ & 86478,3 \\
\hline $\mathrm{T}_{\mathrm{DECK}}(\mathrm{kN} \mathrm{m})$ & 27568,6 \\
\hline $\mathrm{V}_{\text {DECK }}(\mathrm{kN})$ & 5076,6 \\
\hline $\mathrm{M}_{\text {PYLON }}(\mathrm{kN} \mathrm{m})$ & 554635,1 \\
\hline
\end{tabular}

In straight deck configurations, it is observed that bending results obtained in the systems cases are different. This is because each cable has been previously adjusted in order to neutralize deck's initial displacements, according to the procedure described in Chung and Stucchi [3], and therefore tensioned with different values, providing different deck suspensions.

Besides, it was verified that the rigidity of the central pylon influences the ideal strength of cables for control of displacements, which in turn influence in their sustentation. To evaluate these effects, the same models were developed consid-

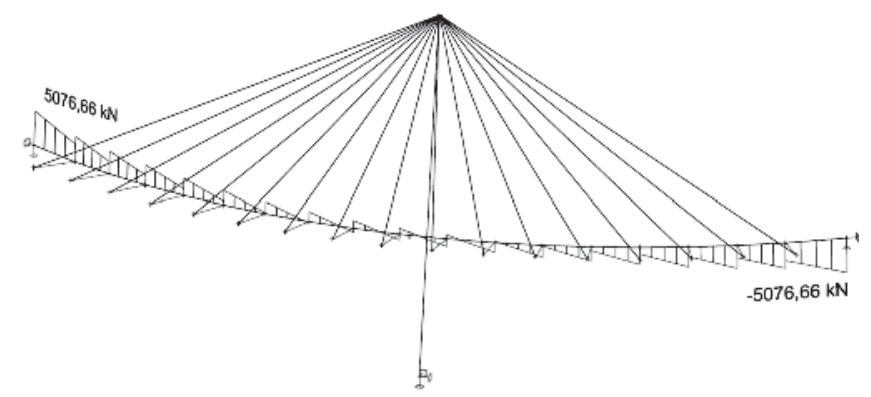

Figure 23

Shear force on curved deck $(\mathrm{P}+\mathrm{L})$ : external case

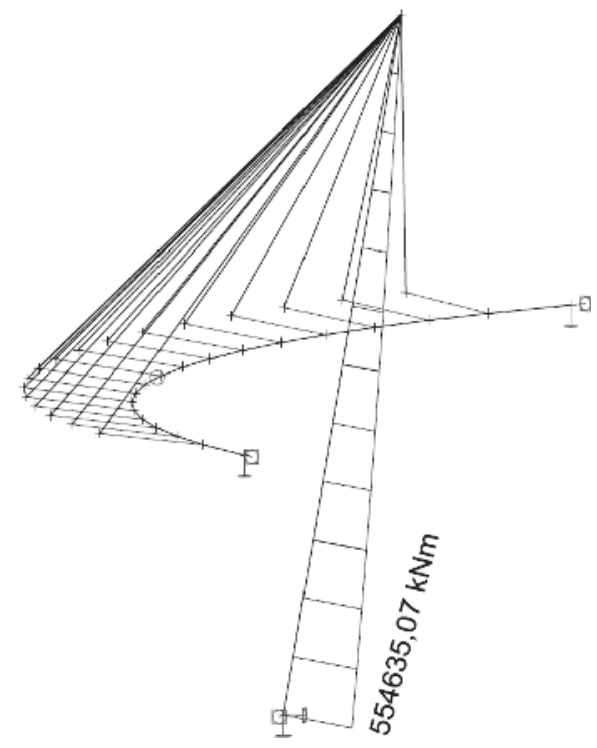

Figure 25

Bending moment on pylon $(\mathrm{P}+\mathrm{L})$ : external case 

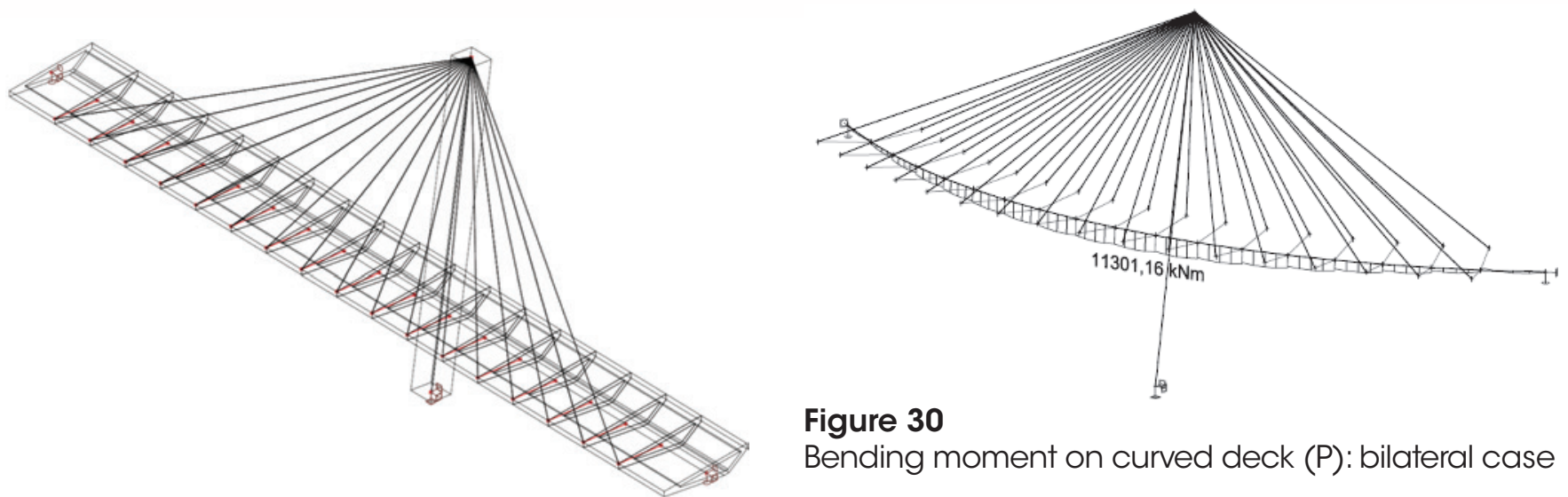

\section{Figure 26}

Model with straight deck: external case

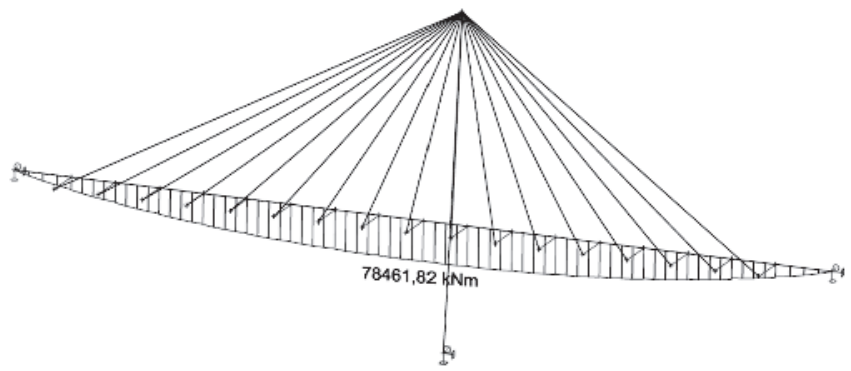

Figure 27

Bending moment on straight deck $(\mathrm{P}+\mathrm{L})$ : external case

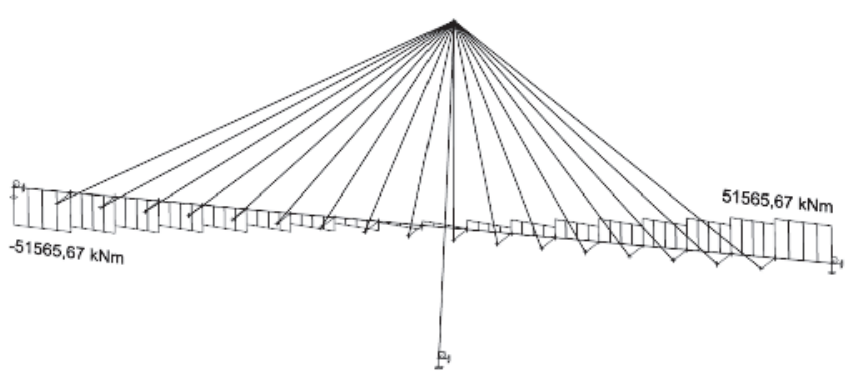

\section{Figure 28}

Torsional moment on straight deck $(\mathrm{P}+\mathrm{L})$ : external case

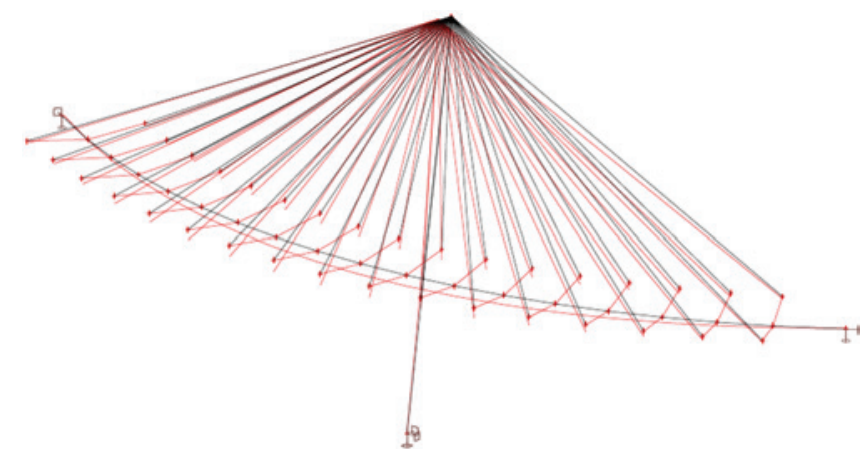

\section{Figure 29}

Deformed configuration: bilateral case

\section{Figure 30}

Bending moment on curved deck (P): bilateral case

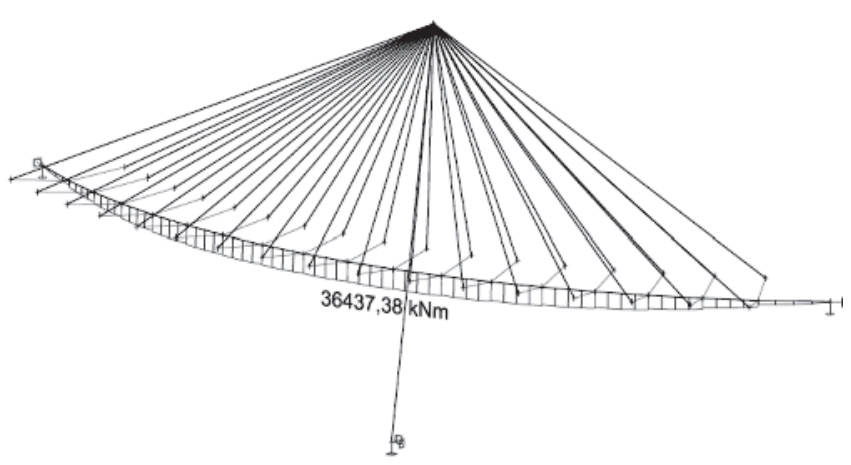

Figure 31

Bending moment on curved deck $(\mathrm{P}+\mathrm{L})$ : bilateral case

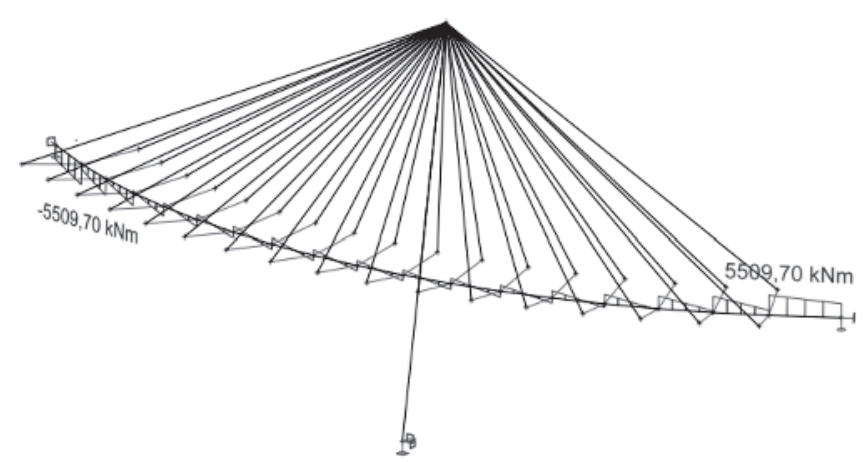

Figure 32

Torsional moment on curved deck (P): bilateral case

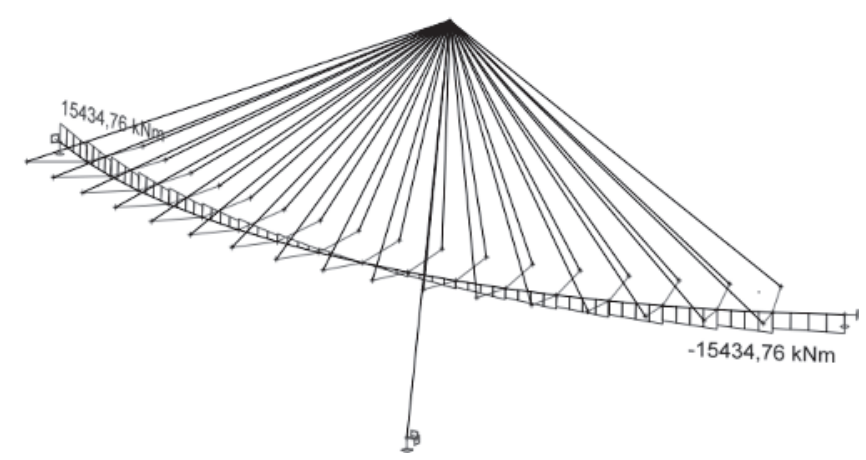

Figure 33

Torsional moment on curved deck $(\mathrm{P}+\mathrm{L})$ : bilateral case 


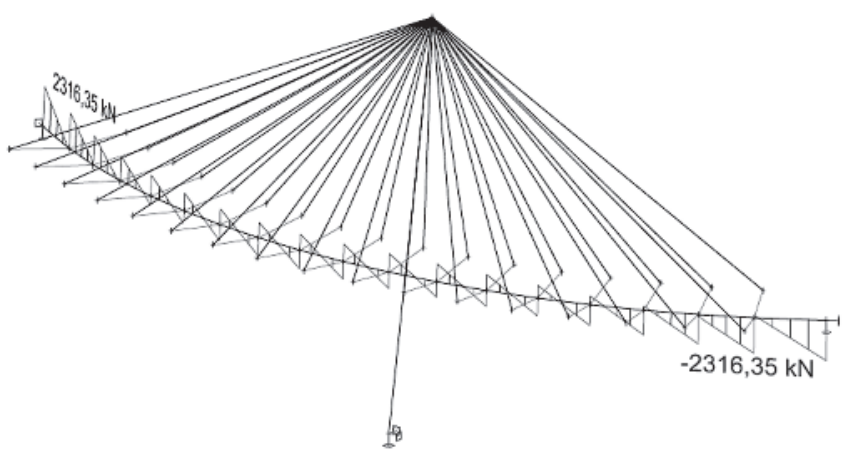

Figure 34

Shear force on curved deck $(P+L)$ : bilateral case

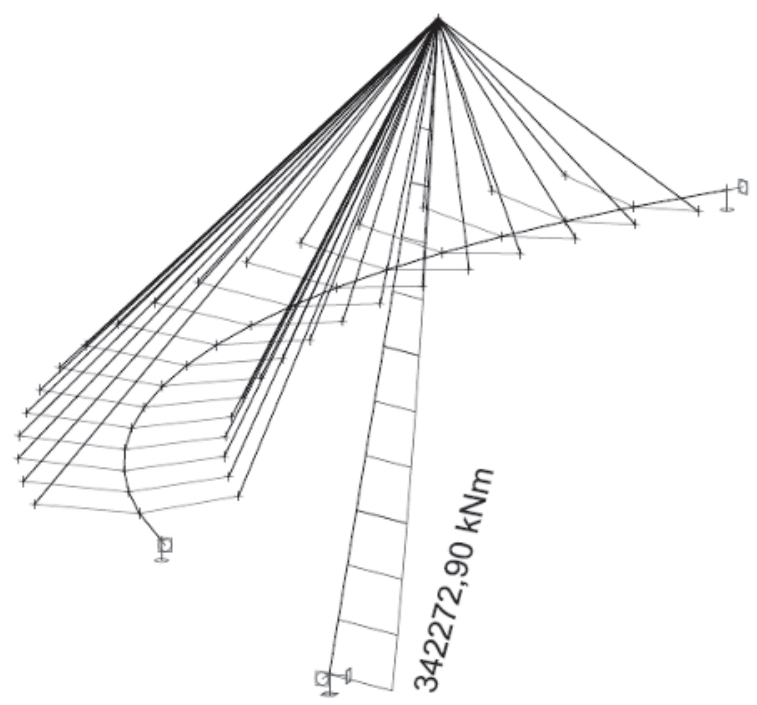

Figure 35

Bending moment on pylon (P): bilateral case

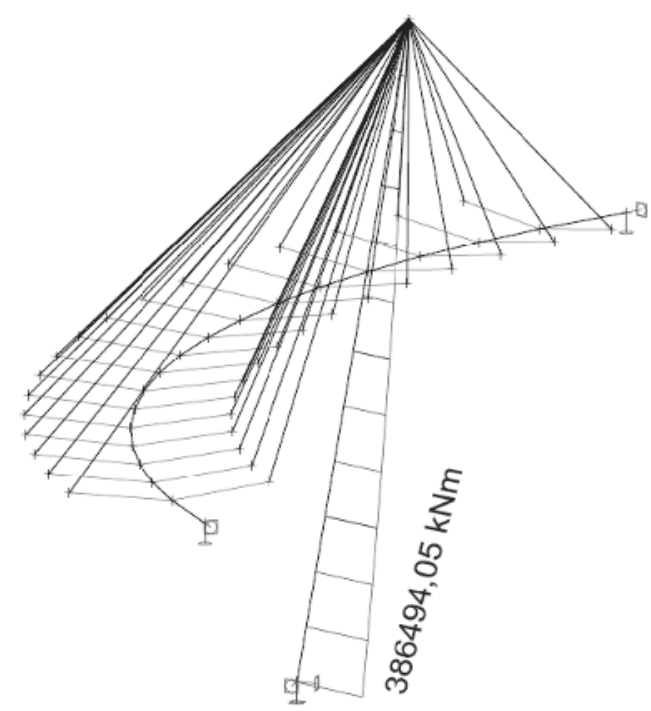

Figure 36

Bending moment on pylon $(\mathrm{P}+\mathrm{L})$ : bilateral case ering a reduction in pylon's section from $5 \times 5 \mathrm{~m}$ to $4 \times 4 \mathrm{~m}$, more flexible.

The results are shown on Table 6.

In this case, bending magnitudes in the deck are larger, as expected, so that to reduce these efforts would be necessary an increase in cable tensioning, and possibly an increase in cables section in order to respect admissible tension.

Finally, the model with bilateral suspension indicated magnitude of solicitations in deck similar to the case of inner side suspension, in case of bending, and similar to the case of outer side suspension, in case of torsion.

\subsection{Conclusions}

The study reveals that in cases of unilateral suspension torsion can be reduced in curved decks when the cables are anchored by the outer side and not by the inner side as might be expected.

\section{Table 4}

Moments and shear force summary in curved deck: bilateral suspension

\begin{tabular}{|c|c|}
\hline Forces & Results \\
\hline $\mathrm{M}_{\mathrm{DECK}}(\mathrm{kN} \mathrm{m})$ & 36437,38 \\
\hline $\mathrm{T}_{\mathrm{DECK}}(\mathrm{kN} \mathrm{m})$ & 15434,76 \\
\hline $\mathrm{V}_{\mathrm{DECK}}(\mathrm{kN})$ & 2316,35 \\
\hline $\mathrm{M}_{\text {PYLON }}(\mathrm{kN} \mathrm{m})$ & 386494,05 \\
\hline
\end{tabular}

Table 5

Comparison of results

\begin{tabular}{|c|c|c|}
\hline Case & $\mathbf{M}_{\text {MAX }}(\mathbf{k N ~ m )}$ & $\mathbf{T}_{\text {MAX }}(\mathbf{k N ~ m})$ \\
\hline $\begin{array}{c}\text { Curved deck } \\
\text { Internal susp. }\end{array}$ & 34087,4 & 130649,8 \\
\hline $\begin{array}{c}\text { Curved deck } \\
\text { External susp. }\end{array}$ & 86478,3 & 27568,6 \\
\hline $\begin{array}{c}\text { Straight deck } \\
\text { Internal susp. }\end{array}$ & 37939 & 110830 \\
\hline $\begin{array}{l}\text { Straight deck } \\
\text { External susp. }\end{array}$ & 78461,8 & 51565,7 \\
\hline
\end{tabular}

\section{Table 6}

Comparison of results: pylon with reduced stiffness

\begin{tabular}{|c|c|c|}
\hline Case & $\mathbf{M}_{\text {MAX }}(\mathbf{k N} \mathbf{m})$ & $\mathbf{T}_{\text {MAX }}(\mathbf{k N} \mathbf{m})$ \\
\hline $\begin{array}{c}\text { Curved deck } \\
\text { Internal susp. }\end{array}$ & 34478 & 130776 \\
\hline $\begin{array}{l}\text { Curved deck } \\
\text { External susp. }\end{array}$ & 98267 & 21679 \\
\hline $\begin{array}{c}\text { Straight deck } \\
\text { Internal susp. }\end{array}$ & 39788 & 100604 \\
\hline $\begin{array}{c}\text { Straight deck } \\
\text { External susp. }\end{array}$ & 90259 & 47818 \\
\hline
\end{tabular}


On the other hand, bending moments in the external suspension system are much higher when compared to the internal system. In addition, the general stress and forces in the structure are better distributed in the internal configuration, especially considering pylon solicitations. That is, the structure shows better overall performance when the cables are anchored on the inner side of the deck. It should also be noted that in configuration with external cables, the attendance to vertical clearance should be taken into account, as the cables pass over the board, which is why it is more common to find curved footbridges suspended unilaterally from the inner side than from the outer side. The bilateral suspension configuration, although efficient, presents the same clearance attendance problem, besides not being as appealing as the internal suspension configuration.

\section{References}

[1] BERGER, D.; STUCCHI, F. R.; HERNANDO, C.; RIBEIRO, C. F. Executive control cable-stayed bridge Octávio Frias de Oliveira. In: Fédération Internacionale du Béton (FIB) Symposium, 11th, London, 2009, Proceedings of the annual international fib symposium. London, 1986.

[2] BARBOSA, R. L. Pontes curvas unicelulares em regime elástico, São Paulo, 1997, Dissertação (mestrado) - Escola Politécnica, Universidade de São Paulo, 167 p.

[3] CHUNG, G.M.; STUCCHI, F. R. Concepção de tabuleiros curvos e estaiados. Revista Concreto \& Construções, São Paulo, v.44, n.84, 2016, p.75-82.

[4] ASSOCIAÇÃO BRASILEIRA DE NORMAS TÉCNICAS. Projeto de estruturas de concreto - Procedimento. - NBR 6118, Rio de Janeiro, 2014.

[5] ASSOCIAÇÃO BRASILEIRA DE NORMAS TÉCNICAS. Carga móvel rodoviária e de pedestres em pontes, viadutos, passarelas e outras estruturas. - NBR 7188, Rio de Janeiro, 2013.

[6] KEIL, A. Weit und krumm. Stahlbau, Berlin, v. 73, n. 12, 2004, p. 982-989

[7] STUCCHI, F. R. Sobre o comportamento estrutural das pontes celulares, São Paulo, 1982, Dissertação (mestrado) Escola Politécnica, Universidade de São Paulo, 1v.

[8] TORNERI, P. Comportamento estrutural de pontes estaiadas: comparação de alternativas, São Paulo, 2002, Dissertação (mestrado) - Escola Politécnica, Universidade de São Paulo, 272 p. 